UDC 621.793

\author{
N. Markocsan, D. Manitsas, J. Jiang, S. Björklund \\ Department of Engineering Science, University West, \\ Trollhättan, Sweden \\ *nicolaie.markocsan@hv.se
}

\title{
MAX-phase coatings produced by thermal spraying
}

This paper presents a comparative study on the Ti ${ }_{2} \mathrm{AlC}$ coatings produced by different thermal spray methods, as Ti ${ }_{2} A l C$ is one of the most studied materials from the MAX-phase family. Microstructural analysis of coatings produced by High Velocity Air Fuel (HVAF), Cold Spray and High Velocity Oxygen Fuel (HVOF) has been carried out by means of the scanning electron microscopy equipped with an energy dispersive spectrometer (EDS). The volume fraction of porosity was determined using the ASTM standard E562. The phase characterization of the as-received powder and as-sprayed coatings was conducted using the X-ray diffraction with CrKa radiation. Impact of the spray parameters on the porosity and the mechanical properties of the coatings are discussed. The results show that the spraying temperature and velocity plays a crucial role in coatings characteristics.

Keywords: MAX-phase, high velocity air fuel (HVAF), high velocity oxygen fuel (HVOF), Cold spray, scanning electron microscopy (SEM).

\section{INTRODUCTION}

The MAX-phase materials are a group of ternary carbides and nitrides with nano-layered structures [1]. MAX is an abbreviation of the general formula: $\mathrm{M}_{n+1} \mathrm{AX}_{n}$ where $\mathrm{M}$ is an early transition metal, $\mathrm{A}$ is an A-group element (most elements are of 13 and 14 groups), $\mathrm{X}$ is either $\mathrm{C}$ and/or $\mathrm{N}$ and $n=1,2,3$. These materials have a hexagonal crystal structures with near close packed layers of the $\mathrm{M}$ elements interleaved with square planar slabs of pure A elements. The $X$ atoms fill the octahedral sites between the $M$ atoms [2]. The A elements are located at the centre of trigonal prisms that are larger than the octahedral X sites [2]. These phases with space group of $\mathrm{P}_{3}$ mmc have two formulas units per the unit cell, where $\mathrm{M}_{n+1} \mathrm{X}_{n}$ layers are interleaved with pure A group layers [3]. There are roughly fifty $M_{2} A X$ [4], five $M_{3} A X_{2}$ [5] and seven $M_{4} A X_{3}$ [6] phases identified so far.

The Mn+1AXn phases are usually classified into three groups based on their $n$ values, i.e., ' 211 ' for $n=1$, ' 312 ' for $n=2$, etc. [7]. In addition, there is also a category of 'intergrown phases' such as the ' 523 ' and ' 725 ' phases, with alternative half unit cell layers of '211' and '312' (='523') or '312' and '413' (=‘725') [7]. The Ti-Al-C system is the most important and stable set of MAX phases due to excellent oxidation resistance at temperatures above $1100{ }^{\circ} \mathrm{C}$ [2]. An insertion of $\mathrm{Al}$ monolayers into a face-centred cubic $\mathrm{TiC}$ matrix implies that the strong $\mathrm{Ti}-\mathrm{C}$ bonds are broken up and replaced by weaker $\mathrm{Ti}-\mathrm{Al}$ bonds with a cost of energy forming a hexagonal close-packed $\mathrm{Ti}_{2} \mathrm{AlC}[2,8]$.

$\mathrm{Ti}_{2} \mathrm{AlC}$ and $\mathrm{Ti}_{3} \mathrm{AlC}_{2}$ are two of the most lightweight and oxidation-resistant MAX phases [9]. Moreover, the accessibility and relatively low cost of their raw

(C) N. MARKOCSAN, D. MANITSAS, J. JIANG, S. BJÖRKLUND, 2017 
materials render them as the most promising for production up-scaling and industrialization. In addition to $\mathrm{Ti}_{2} \mathrm{AlC}$, henceforth referred to as 211 , and $\mathrm{Ti}_{3} \mathrm{AlC}_{2}$, henceforth referred to as 312, there is also a $\mathrm{Ti}_{5} \mathrm{Al}_{2} \mathrm{C}_{3}$ or 523 phase, which is in the category of higher order MAX phases [10]. The combination of both metallic and ceramic properties of $\mathrm{Ti}_{2} \mathrm{AlC}$ originates partially from the metallic nature of the bonding and partially from their layered structure. This unique combination makes them promising for many applications such as electrical heating elements [11], gas burner nozzles in corrosive environments, high temperature bearings [12], cladding materials in lead-cooled fast-breeder nuclear reactors [13], high temperature electrodes [14], etc. Due to their high temperature properties and the stability of thermally grown aluminium oxide, MAX phases are also considered as an alternative to MCrAlY-coatings for applications in hot gas corrosion protection, e.g., as coating for turbine blades [15].

Physical vapour deposition and chemical vapour deposition are apart from solid-state reaction synthesis, the most used techniques for thin-film deposition of MAX phase materials [16]. Sputtering from M, A, and graphite targets is the common method for laboratory scale synthesis in order to produce MAX carbides, including $\mathrm{Ti}_{2} \mathrm{AlC}$ and $\mathrm{Ti}_{3} \mathrm{AlC}_{2}$ [17]. Also, $\mathrm{Ti}_{2} \mathrm{AlC}$ has been deposited by sputtering from compound targets [18]. Moreover, Rosen et al. [19] have reported synthesis of epitaxial $\mathrm{Ti}_{2} \mathrm{AlC}$ using a pulsed cathodic-arc setup from elemental $\mathrm{Ti}$, $\mathrm{Al}$, and $\mathrm{C}$ cathodes at a substrate temperature of $900{ }^{\circ} \mathrm{C}$. In order to step forward toward ticker MAX-phase coatings, alternative coating processes have been considered.

The thermal spray methods are potential processing approaches to fabricate $\mathrm{Ti}_{2} \mathrm{AlC}$ coatings on large engineering components [15]. Several attempts have been made to process $\mathrm{Ti}_{2} \mathrm{AlC}$ coatings by high velocity oxy-fuel (HVOF) [20-22] and cold spraying (CS) [19] techniques. In the CS process the in-flight particle is not melted so the material phase and chemical composition can be preserved [23]. Moreover, the low temperature of the process enables the deposition of coatings with low and/or compressive residual stress [24], low porosity, and low-oxygen content [25]. However, there are two major concerns about cold spray of MAX phase coatings: the bond strength between the coating and the substrate, and the coating thickness [26]. A coating is reliable and functional only when it has a good adhesion to its substrate [26]. The bonding of particles in cold spray is presumed to be the result of extensive plastic deformation and related phenomena at the interface, such as spray jet formation and spray splats interlocking. As MAX phases are hard materials, the sprayed powder particles deform very little under the impact with the substrate and adhere poorly; hence it is difficult to deposit coatings thicker than $100 \mu \mathrm{m}$ [27].

HVOF spraying gives the possibility to make denser and less oxidized coatings compared to the plasma spraying, though due to a rather high flame temperature (i.e., $2600-3100{ }^{\circ} \mathrm{C}$ ) it is limited when it is used for spraying materials which are sensitive to higher temperatures, i.e., depletion, oxidation, decomposition. Preliminary attempts showed that quite a high amount of the sprayed MAX material dissociate due to the high spraying temperature when sprayed by HVOF and thus the excellent properties of these materials are entirely preserved [20-22].

A HVAF (High Velocity Air Fuel) system uses gas or liquid fuel and compressed air as combustion gases which leads to significantly lower flame temperatures than in the HVOF process (i.e., $1400-1800{ }^{\circ} \mathrm{C}$ ) [28]. HVAF uses also a higher spraying velocity, which in turn leads to denser coatings, compressive stresses in coatings, and less degree of the oxidation [29]. Therefore, the HVAF process can be considered the link between the high velocity combustion spray processes and 
cold gas spraying while retaining the capability to produce superior and thicker coatings [30]. In addition, HVAF is a less expensive spraying process, hence it is industrially attractive and easy to scale-up for mass production [31]. To the best of the authors, no previous works on HVAF spraying of MAX phase materials were reported.

The objective of this study was focused on deposition and investigation of thick $\mathrm{Ti}_{2} \mathrm{AlC}$ coatings by high velocity oxy fuel, high velocity air fuel, and cold spraying processes. Special emphasis was on the HVAF coatings as this process was firstly used for spraying the MAX materials.

\section{EXPERIMENTAL PROCEDURE}

\section{Materials}

The feedstock material used in this study was a $\mathrm{Ti}_{2} \mathrm{AlC}$ powder (MAXTHAL $211 \circledR)$ produced by Kanthal AB. The MAXTHALL $211{ }^{\circledR}$ is classified as a machinable engineering ceramic. The powder was manufactured from crushed and sifted $\mathrm{Ti}_{2} \mathrm{AlC}$ bulk material sieved down to $\sim 230$ mesh. The chemical composition of the powders is $50.1 \% \mathrm{Ti}, 25.5 \% \mathrm{Al}, 23.5 \% \mathrm{C}, 0.3 \% \mathrm{Si}, 0.6 \% \mathrm{O}$ and $0.05 \% \mathrm{Fe}$.

Stainless steel coupons of $60 \times 19 \times 1.5 \mathrm{~mm}$ (AMS 5604, US standard) were used as substrate specimens.

\section{Samples production}

Three spraying methods have been employed to produce the coatings:

a) HVOF spraying, done with a Diamond JetTM 2600 gun equipped with a Diamond JetTM 7-8 nozzle (Sulzer Metco) and air-cooled combustion chamber. A gas mixture of $\mathrm{H}_{2} / \mathrm{O}_{2}$ was used as the spraying gas. The samples were cooled during spraying with compressed air.

b) HVAF spraying, performed with a M3 spray gun equipped with a 4L2 nozzle (UniqueCoat Technologies), using a supersonic air fuel technology. A reactive mixture of air and propylene was used as the spraying gas.

c) CS performed with a CGT Kinetiks 4000/47 cold spray system using nitrogen as the process gas and a PF4000 (CGT, Ampfing, Germany) powder feeder.

The spraying parameters used for the three processes are shown in Table 1. Preliminary parameters optimisations were done for the HVOF and CS processes.

Table 1. Parameters of thermal spray processes

\begin{tabular}{c|ccc}
\hline Coating code & HVOF & HVAF & CS \\
\hline Gun & DJ 2600 (HVOF) & M3 (HVAF) & CGT Kinetiks 4000/47 \\
Gas & Fuel/oxygen & Propylene pressure: & Nitrogen pressure: \\
& ratio & $0.68 \mathrm{MPa}$ & $3.7 \mathrm{MPa}$ \\
& 0.3 & Air pressure: 0.74 MPa & \\
Powder feed rate, g/min & $21-22$ & $18-22$ & $5-6$ \\
Carrier gas flow, L/min & 953 & 20 & 60 \\
Spraying distance, mm & 230 & 305 & 20 \\
Number of torch passing & 10 & 12 & 3 \\
\hline
\end{tabular}

The spray parameters used in the HVAF spray trial were standard spray parameters (given by the equipment manufacturer) for spraying cermet materials. 


\section{SAMPLES CHARACTERIZATION}

\section{Metallographic preparation}

The samples were cut with a Struers Secotom-10 cutting system using water based lubricant and a diamond cut-off wheel. Hot compression mounting (SimpliMet 2000) was used for metallographic preparation. The resin used for SEM investigations was KonductoMet 20-3375-400. The samples were polished in 4-steps using a Buehler Hercules $\mathrm{H}$ disk and diamond slurries. After polishing the coupons were rinsed with water, then with methanol and dried with hot air.

\section{Microstructure investigation}

The morphology of the powder and coatings microstructure were examined by means of a Scanning Electron Microscope (Hitachi TM3000) with acceleration voltage $15 \mathrm{kV}$, equipped with Energy Dispersive X-ray Spectrometer (EDS). Observations were carried out on metallographic samples. Backscattered electron (BSE) images were obtained to reveal the different phases and the EDS analysis was performed on the individual phases to obtain their elemental composition. The BSE images and EDS spectra were taken with primary electron beam energy of $15 \mathrm{keV}$, and of $0.5 \mathrm{~mm}$ depth focus. At this accelerating voltage, SEM/EDS analyses typically include information from a pear-shaped interaction volume of at least $1 \mu^{3}$. It should be emphasized that the atomic percent of $C$ as determined by EDS is only approximate. When analyzing the MAX phase via X-ray mapping, only larger particles were analyzed with high magnification in order to minimize an influence of the composition from the surrounding matrix. The EDS analysis of five points gives an estimation of the composition of each phase.

\section{Porosity evaluation}

The porosity of the coatings was evaluated according to the ASTM E562-08 by a visual point counting on 40 evenly distributed fields with 100 points-layer each, across the whole cross-section of the sample. The investigations were performed on the SEM micrographs.

\section{Phase analysis}

The phase characterization of the as-received powder and the as-sprayed coatings was carried out using an X-ray diffractometer with $\mathrm{CrK \alpha}$ radiation (wavelength $=0.2291 \mathrm{~nm}$ ) at $35 \mathrm{kV}$ and $30 \mathrm{~mA}$. The $2 \theta$ range was varied from $30^{\circ}$ to $150^{\circ}$ with a step size of $0.04^{\circ}$ and a step time of $16 \mathrm{~s}$. It should be pointed out that in our study the XRD patterns were plotted according to $\mathrm{CuKa}$ radiation.

\section{Microhardness evaluation}

The micro-Vickers hardness measurements were carried out with a Shimadzu Microhardness Tester on the polished cross section of the samples according to the ASTM E384-10 at loads of $100 \mathrm{~g}(980.7 \mathrm{mN})$ and $500 \mathrm{~g}(4.903 \mathrm{~N})$ and dwell time of $15 \mathrm{~s} . H_{V} 0.1$ and $H_{V} 0.5$ were calculated from averaging series of 20 indentations. The distance between the centres of the two indentations was at least 4 times the diameter of the indentation. Also the distance from the centre of the hardness indentation to the edge and the substrate in the test was at least 3 times the diameter of the indentation. A series of 20 indentations were made on each coating, which were distributed evenly in a half circle of the entire test panel.

\section{Roughness measurement}

The surface roughness $(R a)$ of the as-sprayed coatings were measured with a Mitutoyo (SURFTEST 301) roughness tester. 


\section{RESULTS AND DISCUSSION}

\section{Powder morphology}

Figure 1 shows the morphology of the MAXTHAL ${ }^{\circledR} 211$ powder used in this study. The $\mathrm{Ti}_{2} \mathrm{AlC}$ powder particles are flake-like and irregular. Also, the nonuniform shape and size of the powder are obvious. The results of the morphological investigation are consistent with similar works done previously [6, 20, 22]. The $\mathrm{Ti}_{2} \mathrm{AlC}$ walls have both tilt and twist components. The distinctive layered structure can be easily seen, as well as the kinks at the fracture surface. The images reveal that the powder consists of three characteristic types of grains, or more specifically, conglomerates assembled from micro-scale grains, flake-like grains with cleavage steps and kinked laminates.
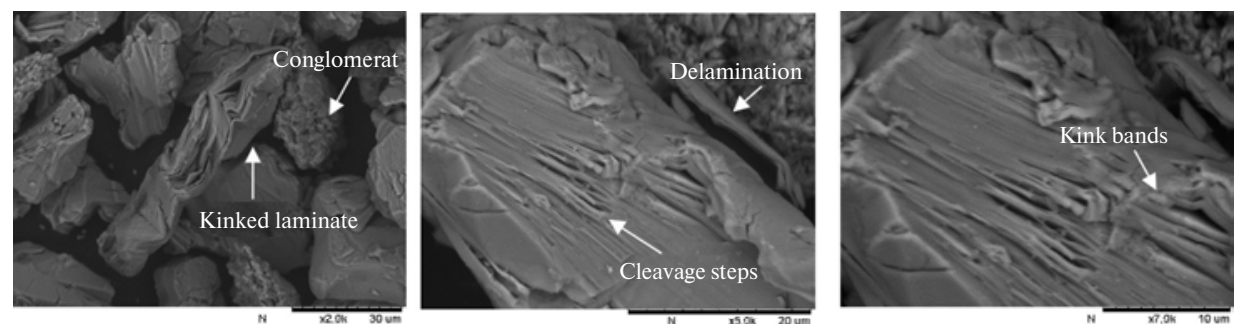

Fig. 1. Powder morphology; of the MAXTHAL $211^{\circledR}$ as SEM-BSE micrograph; $\mathrm{Ti}_{2} \mathrm{AlC}$ material is nano-laminate, assemblage of microscopic layers analogous to the flaky phyllo dough.

Cleavage steps and dislocations are typical for the (000l) basal planes, with $l=$ odd [14]. As showed by Guo et al. [32], the dislocations arrange themselves either in arrays (pile-ups) on the same basal planes, or in walls (low- and high-angle grain boundaries) normal to the basal planes, as they are confined to the basal planes. Kink banks can also be seen in Fig. 1. As found by Hess et al. [33], kink bands form in a crystalline solid when dislocations form and move in opposite directions (small $\mathrm{T}$ symbols in the diagram), settling into a configuration with well-defined kink boundaries. Note that kink bands are expected only in crystals that do not twin, such as hexagonal metals or alloys having an axial c/a ratio greater than $\sim 1.73$ [34]. Each kink band is composed by pairs of dislocations with opposite Burgers vector organized in walls perpendicular to the basal plane [35].

\section{Coatings microstructure}

The microstructure images of the as-sprayed coatings, sprayed by different techniques, are shown in Fig. 2 and marked as follows $a-c$ HVAF, $d-f$ HVOF and $g-i$ CS. The HVAF coating revealed a well-bonded and homogeneous structure, where the sprayed layers are almost indistinguishable. This might be attributed to the densification effect caused by the peening of the particles impacting the substrate/coating with high velocity. Figure 2, $a$ is a cross-sectional SEM-BSE image of a $\sim 310 \mu \mathrm{m}$ thick $\mathrm{Ti}_{2}$ AlC coating on stainless steel substrate. The HVAF coating has a top surface roughness $(R a)$ of $8 \mu \mathrm{m}$ (Table 2$)$. The interface between the HVAF coating and substrate is compact with no obvious voids or delaminations. The HVAF micrographs reveal two types of regions in the coating, one containing larger grains and the other consisting of very small grains. Additionally, the small grains are embedded in a dark-grey appearing phase. These distinguished regions can be a result of the relatively large powder size interval, so that both very small and large particles form the coating. These types of features were observed on the HVOF coatings too and can be more clearly seen in Fig. 3. In Fig. 2, a it can be 
observed also an embedded grit residue on the substrate surface, which is an alumina particle with sharp, angular cutting edges that remain stuck in the substrate's asperities from the grit blasting process.
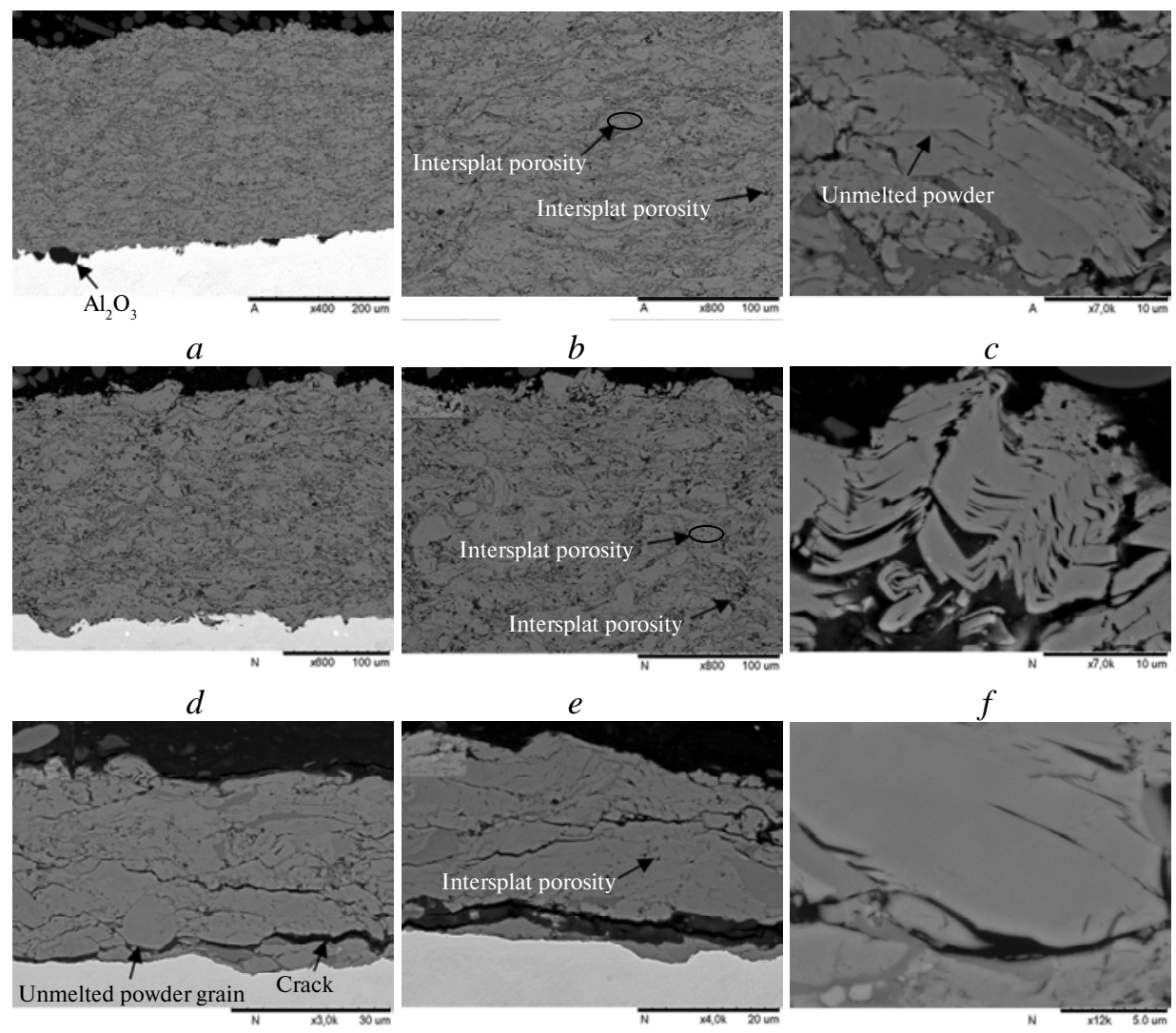

$g$

$h$

i

Fig. 2. SEM-BSE micrographs of the cross section of $\operatorname{HVAF}(a-c), \operatorname{HVOF}(d-f)$ and CS $(g-i)$ MAX phase coatings.

Table 2: Roughness measurements results

\begin{tabular}{c|c}
\hline Coating type & Surface roughness $R a, \mu \mathrm{m}$ \\
\hline HVAF & $8 \pm 0.8$ \\
HVOF & $6 \pm 0.5$ \\
CS & $5 \pm 0.5$ \\
\hline
\end{tabular}

Figure $2, d$ shows a cross-sectional SEM-BSE image of $\sim 210 \mu \mathrm{m}$ thick HVOF coating. The HVOF coating has a top surface roughness $(R a)$ of $6 \mu \mathrm{m}$ (see Table 2). Lower roughness of a coating sprayed with same powder but by different thermal spray process may indicate a larger melting rate of the particles so that they become more "flattened" under the impact to substrate. High melting rate is not desired for MAX-phase materials as it can lead to a higher degree of dissociation during spraying and thus new phases can appear in the coating.

Both HVAF and HVOF coatings are relatively dense, showing a specific layered splat structure. However, unmelted powder grains of $\mathrm{Ti}_{2} \mathrm{AlC}$ are also embedded in the coatings. 


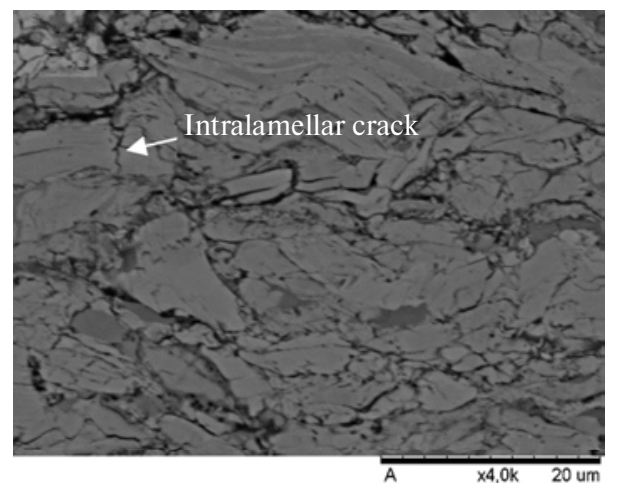

$a$

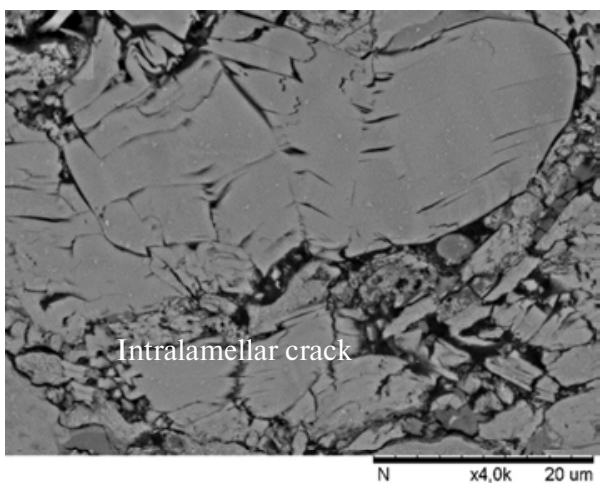

$b$

Fig. 3. Specific microstructural features of $\operatorname{HVAF}(a)$ and $\operatorname{HVOF}(b)$ MAX phase coatings.

The coating deposited by the CS process (see Figs. 2, $g-i$ ) exhibits a threelayered structure, since three single layers stacked one upon the other. It is a $\sim 55 \mu \mathrm{m}$ thick coating with bad adherence to its substrate as large disbonded areas were observed. The CS layers displayed a bad inter-locking and they are clearly separated by continuous transversal cracks. This indicates a weak cohesion of the coating and consequently difficulty to increase the coating's thickness. As expected, it is visible a remarkable plastic deformation of the sprayed particles, which is a typical feature of the cold spray deposition.

The roughness of the CS coatings was $R a 5 \mu \mathrm{m}$ which, if compared to the other two coatings, may indicate either a better flattening effect of the particle (better than those sprayed by HVOF and almost same with those sprayed by HVAF) or that the big particles have not adhered but only the very small ones.

As the coatings could not be sprayed thicker than $55 \mu \mathrm{m}$ and even so with large disbonding areas, it can be concluded that $\mathrm{Ti}_{2} \mathrm{AlC}$ powder is usable in a very limited scale for cold spray deposition.

The overall porosity levels that were measured on coatings are shown in Fig. 4. The porosity of the HVAF sprayed coating was found to be around $2 \mathrm{vol} \%$, on the other hand the porosity of coating produced by the HVOF process was higher, around 6 vol \%. Because of the very small thickness of the CS coatings and also because of their large cracks and large disbonded areas, the porosity measurement routine used for HVAF and HVOF coatings was not possible to be used for CS coatings. However, using an image analysis method, that allows measuring porosity from coating's microstructure, it was found out that the CS coatings porosity values are between those of HVAF and HVOF, i.e., around $3 \mathrm{vol} \%$. The scatter in the porosity results on HVAF, HVOF, and CS coatings is rather small, the standard deviation values for each of the measurements varies between $0.3,1$ and 0.3 respectively.

The coatings presented a bimodal porosity. One type of pores of the bigger size consisted of globular voids and cracks formed at the splats interfaces and probably formed by a partial overlapping of two consecutive splats so that gaps remained between them, which in this case are the remaining pores in the coating (see Fig. 2). Intra-lamellar cracks were observed as well (see Fig. 3). Cracks could form either under the impact and solidification of the particle or after spraying when the substrate cooled down to room temperature so that the mismatch between the thermal expansions of the two materials was high enough to induce cracks in the coating. The found pores of the second type are of a very low scale and are located either at the interface of the very small particles or within the splats. This type of 
porosity mostly comes from the powder (i.e., from the manufacturing process); (see Fig. 1) and lack of a good compacting of the coatings under spraying (i.e., the kinetic energy and/or softening degree of the particles are not high enough to deform/flatten well the particle under impact hence the pores preserved in the particle are new and formed at the interface). Nano-laminate and kink-band type small cracks (delaminations) can be seen in all coatings investigated in this study. As regards bigger (macro) cracks, it can be observed that the HVOF coating has a higher density of cracks compared to HVAF coatings (see Fig. 2). However both HVOF and HVAF coatings have significantly lower amount of cracks than the CS coatings.

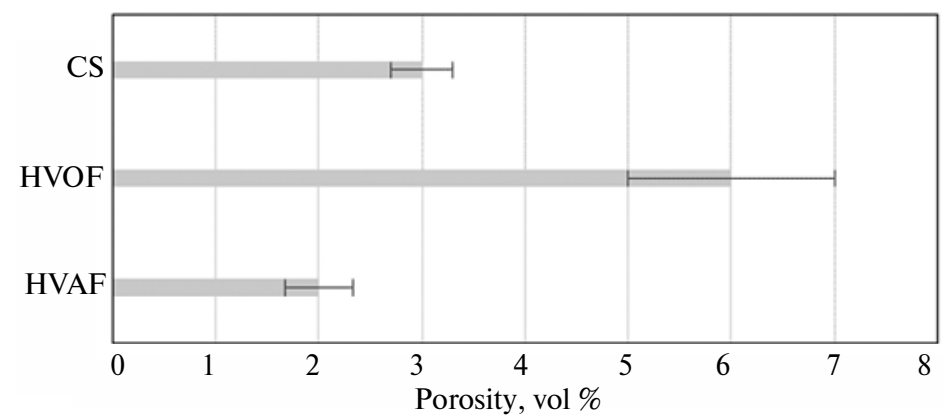

Fig. 4. Porosity values of the sprayed coating.

The more porous microstructure of the HVOF process has resulted in lower microhardness of the coatings (Fig. 5). The lower hardness values can reflect also the higher decomposition ratio of the particles in the HVOF coatings, i.e., the new phases have lower hardness values than $\mathrm{Ti}_{2} \mathrm{AlC}$. The hardness measurement could not be carried out on the cold sprayed samples due to the low thickness and low adhesion of the coatings.

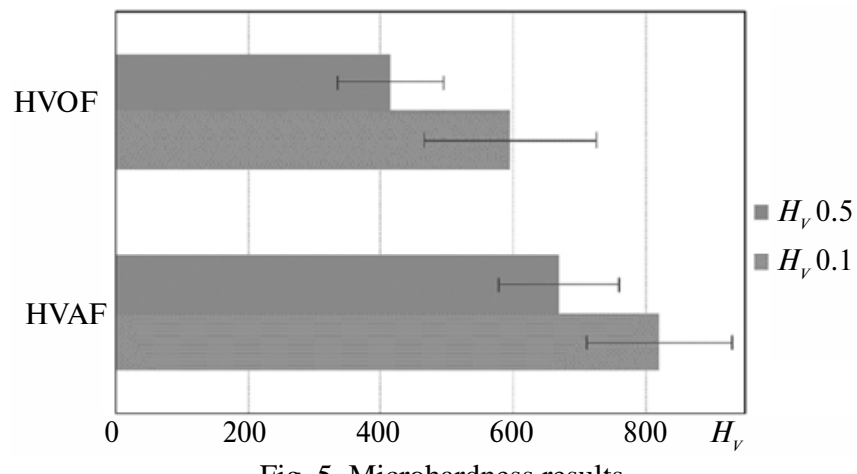

Fig. 5. Microhardness results.

The melting ratio and velocity of the particles at the point of impact on the substrate are the variables that directly influence the coating microstructure and porosity, which, in turn, determine coating strength and hardness.

Figure 6 shows the distribution of elements by the EDS mapping. Quantitive EDS analysis indicates that the light-grey regions correspond to small islands rich in Ti. The map together with the point analysis reveals that thin Al-rich zones surround the large Ti-rich grains as well as the small-grained regions. The darker grey, minority phase, is an Al-Ti intermetallic. At almost 2, the $\mathrm{Al}$ : Ti ratio suggests that 
its chemistry is $\mathrm{TiAl}_{2}$. Futheremore, it was found that the HVAF sprayed coating has the highest Ti content (the light grey phase) comparing to HVOF and Cold Spray deposition. It should be pointed out that the higher content of light elements in coatings gives the darker contrast in SEM-BSE image.

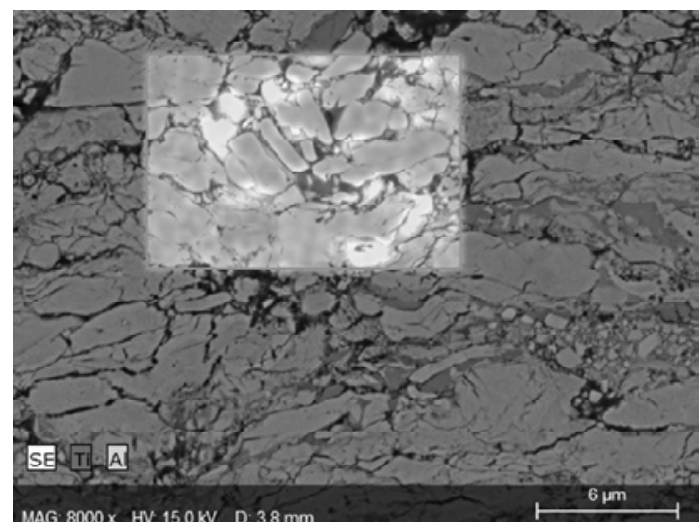

Fig. 6. EDS Map analysis, SEM image of HVAF sprayed MAX phase coating.

In an attempt to find XRD evidence for the Ti-Al-C system, a XRD scan was carried out on coatings investigated in this study as well as on the feedstock powder. The XRD pattern of the feedstock powder shows the characteristic peaks of $\mathrm{Ti}_{2} \mathrm{AlC}$ phase (Table 3). For comparison purposes in Table 3 are presented both the measured values (using $\mathrm{CrK} \alpha$ radiation sources) and the corresponding $\mathrm{CuK \alpha}$ values taken from the literature [26]. Other phases such as $\mathrm{TiC}$ and $\mathrm{Ti}_{x} \mathrm{Al}_{x}$ are also present. Previous studies have shown that $\mathrm{TiC}$ and $\mathrm{TiAl}$ can be either the intermediate phases during the synthesis of $\mathrm{Ti}_{2} \mathrm{AlC}$ or the impurities of the $\mathrm{Ti}_{2} \mathrm{AlC}$ ceramic [26, 36-39].

Table 3. Miller indices, CrKa and CuKa radiation peaks

\begin{tabular}{|c|c|c|c|c|c|c|c|c|c|c|c|}
\hline Peak (20-degree), CrKa & 50,49 & 51,52 & 54,72 & 260,04 & 60,63 & 63,88 & 67 & 79,04 & 82,96 & 89,64 & 97,04 \\
\hline Miller indices & 311 & 200 & 111 & 311 & 311 & 111 & 220 & 311 & 200 & 211 & 311 \\
\hline Phase & $\mathrm{Ti}_{3} \mathrm{AlC}_{2}$ & $\mathrm{TiC}$ & $\mathrm{TiC}$ & $\mathrm{Ti}_{2} \mathrm{Al}$ & $\mathrm{Ti}_{3} \mathrm{AlC}_{2}$ & $\mathrm{TiC}$ & $\mathrm{Ti}_{x} \mathrm{Al}_{x}$ & $\mathrm{Ti}_{2} \mathrm{AlC}$ & $\mathrm{TiC}$ & $\mathrm{Ti}_{2} \mathrm{AlC}$ & $\mathrm{Ti}_{2} \mathrm{AlC}$ \\
\hline
\end{tabular}

When the XRD diffractograms of HVAF, HVOF, and CS deposited MAX phase coatings are compared (Fig. 7), it is obvious that diminution of the peak intensities belong to $\mathrm{Ti}_{2} \mathrm{AlC}$, peak broadening, and an emergence of peaks belonging to $\mathrm{Ti}_{3} \mathrm{AlC}_{2}$ and $\mathrm{TiC}$ occurred, when compared to the un-sprayed powder. Additionally, there are peaks corresponding to $\mathrm{Ti}_{2} \mathrm{AlC}, \mathrm{Ti}_{3} \mathrm{AlC}$, and titanium aluminides $\mathrm{Ti}_{x} \mathrm{Al}_{x}$. If compared the coatings with the as-received powder, the $\mathrm{X}$-ray diffractograms show stronger intensities of the undesired polycrystalline TiC in two peaks $54.72^{\circ}$ and $63.88^{\circ}$. However, the polycrystalline TiC is more pronounced in the samples produced by the HVOF and CS processes than in those produced by the HVAF. It is an interesting result as the spray temperature of the HVAF process is, in terms of particle's velocity and temperature, between HVOF (that is hotter and slower) and CS (that is colder and faster). This may show that not only particle temperature is important during spraying (which can obviously contribute to a phase alteration) but also the particle's velocity which can have a similar influence. 
More experimental work is needed to completely elucidate and understand the phenomena behind these results.

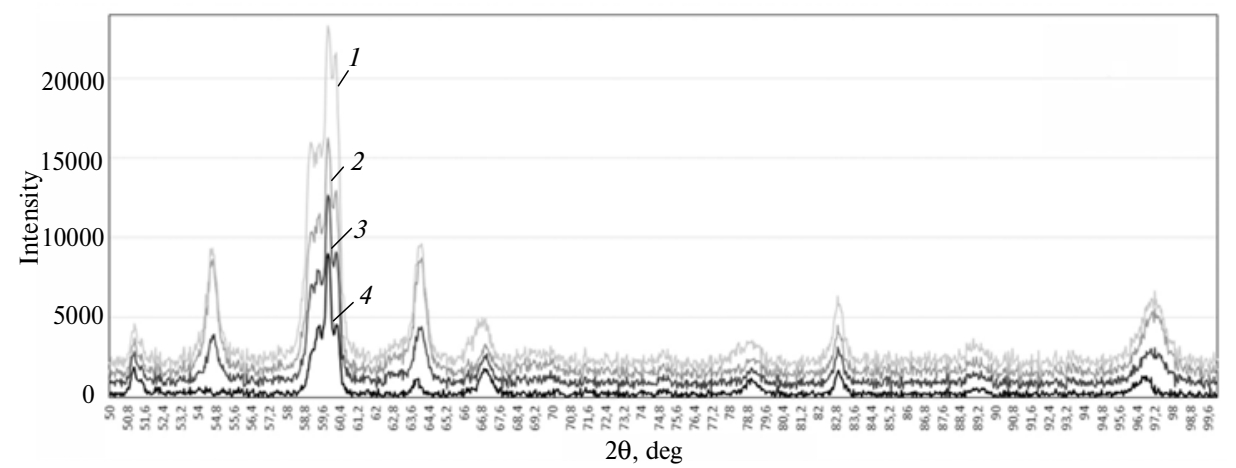

Fig. 7. XRD patterns of feedstock powder and coating: $1-\mathrm{Ti}_{2} \mathrm{AlC} \_\mathrm{CS} ; 2-\mathrm{Ti}_{2} \mathrm{AlC} \_$HVOF; $3-$ $\mathrm{Ti}_{2} \mathrm{AlC} \_$HVAF; 4 - $\mathrm{Ti}_{2} \mathrm{AlC} \_$Powder.

According to the discussion above, it can be said that during the spray deposition processes the $\mathrm{Ti}_{2} \mathrm{AlC}$ powder decomposes. The microstructure of the coatings is built up of layers of unmelted and partially melted, decomposed $\mathrm{Ti}_{2} \mathrm{AlC}$ grains embedded in a mixture of $\mathrm{Ti}_{x} \mathrm{Al}_{x}$ and TiC grains. As clarified by Sonestedt et al. [40] it appears that during the spraying process, the outer part of the grains melt or partially melt, and oxidize while the interior of the grains start to suffer from outward diffusion of aluminium. Figure 2 shows that the $\mathrm{Ti}_{2} \mathrm{AlC}$ grain corresponds to the unmelted core of the powder grains while the alleged outward diffusion of $\mathrm{Al}$ is result in an $\mathrm{Al}$ rich phase surrounding this grain. The decomposition of $\mathrm{Ti}_{2} \mathrm{AlC}$ by $\mathrm{Al}$ outward diffusion is also supported by the fact that in this structure the Ti-Al bonding is weaker than that between $\mathrm{Ti}$ and $\mathrm{C}$ and that the decomposition of closely related structure of $\mathrm{Ti}_{3} \mathrm{AlC}_{2}$ is triggered by deintercalation of $\mathrm{Al}$ [41]. The promising results shown by the HVAF samples can be an effect of the beneficial combination of the low heat and particle velocity that the HVAF process possesses so that the transferred thermal energy is just enough to soften the particle while the high velocity of the particle makes it to impact strongly the substrate and give a good cohesion and adhesion to the coating. However, more experimental work needs to be done in order to optimise the effect of the two energies on the in-flight particle so that the TiC phase apparition is even more restrained.

\section{CONCLUSIONS}

An experimental study has been carried out on $\mathrm{Ti}_{2} \mathrm{AlC}$ (MAX-phase) coatings produced by 3 thermal spray methods, namely, HVOF, HVAF, and CS. While the initial proportion of the MAX-phase is difficult to be retained in the sprayed coatings, all the investigated methods showed both advantages and disadvantages. The CS spraying method shows limitation in producing highly cohesive and thick coatings. This issue can be solved by using thermal spray methods such as HVOF and HVAF. However, the high temperature that is common for these processes is a major obstacle in preserving the MAX-phases in the coating as it dissociate at elevated temperature. Despite the obvious difficulties in producing MAX-phase coatings by thermal spray methods the HVAF process is the most promising one. It seems that the good balance between the low heat transfer and high velocity of the particle makes possible to produce thicker coatings, which also shows a lower thermal degradation than the HVOF samples, so that the desired $\mathrm{Ti}_{2} \mathrm{AlC}$ phase can 
more successfully preserved. The large interval of setting the spray temperature gives the premises that further spray optimization work can result in highly functional HVAF coatings with high content of MAX phases.

\section{ACKNOWLEDGMENTS}

The authors would like to thank Richard Trache for carrying out the XRD tests. Thanks to Professor Dimitris Anagnostopoulos from University of Ioannina for his help in processing the XRD analysis.

Представлено порівняльне дослідження покриттів $\mathrm{Ti}_{2} \mathrm{AlC}$, отриманих різними методами термічного розпилення, оскільки $\mathrm{Ti}_{2} \mathrm{AlC} \epsilon$ одним з найбільш вивчених матеріалів з сімейства фаз МАХ. Мікроструктурний аналіз покриттів, шо вироблено високошвидкісним відпалом на повітрі (HVAF), холодним розпиленням та високошвидкісним відпалом у середовищі кисню (HVOF), проведено за допомогою скануючого електронного мікроскопа, оснащеного енергодисперсійним спектрометром (EDS). Об'ємну частку пористості визначали за стандартом АSTM Е562. Фазовий склад вихідних порошків $i$ покриттів, щзо отримано розпиленням, проводили за допомогою рентгенівської дифракції з СгКа-випромінюванням. Зроблено аналіз впливу параметрів розпилення на пористість та механічні властивості покриттів. Результати показали, що температура $і$ швидкість розпилення відіграють вирішальну роль у характеристиках покриттів.

Ключові слова: МАХ-фаза, високочвидкісний відпал на повітрі (HVAF), високошвидкісний відпал у середовищі кисню (HVOF), холодне розпилення, скануюча електронна мікроскопія (SEM).

Представлено сравнительное исследование покрытий $\mathrm{Ti}_{2} \mathrm{AlC}$, полученных различными методами термического распыления, поскольку Ti 2 AlС является одним из наиболее изученных материалов из семейства МАХ-фаз. Микроструктурный анализ покрытий, полученных высокоскоростным отжигом на воздухе (HVAF), холодным напылением и высокоскоростным отжигом в среде кислорода (HVOF), проводили с помощью сканирующего электронного микроскопа, оборудованного энергодисперсионным спектрометром (EDS). Объемную долю пористости определяли по стандарту ASTM E562. Фазовый состав исходных порошков и покрытий, полученных распылением, проводили с использованием рентгеновской дифракции с С СК $\alpha$-излучением. Проанализировано влияние параметров распыления на пористость и механические свойства покрытий. Результаты показывают, что температура и скорость распыления играют решающую роль в характеристиках покрытий.

Ключевые слова: МАХ-фаза, высокоскоростной отжиг на воздухе (HVAF), высокоскоростной отжиг в среде кислорода (HVOF), холодное напыление, сканирующая электронная микроскопия (SEM).

1. Barsoum $M$. W. The MN+1AXN phases: A new class of solids: Thermodynamically stable nanolaminates // Prog. Solid State Chem. - 2000. - 28, N 1-4. - P. 201-281.

2. Magnuson M., Wilhelmsson O., Palmquist J.-P. et al. Electronic structure and chemical bonding in $\mathrm{Ti}_{2} \mathrm{AlC}$ investigated by soft X-ray emission spectroscopy // Phys. Rev. B. - 2006. $\mathbf{- 7 4}$. - P. 195-208.

3. Nowotny $V$. H. Strukturchemie einiger Verbindungen der Übergangsmetalle mit den elementen C, Si, Ge, Sn // Prog. Solid State Chem. - 1971. - 5. - P. 27-70.

4. Dubois S., Cabioc'h T., Chartier P., et al. A new ternary nanolaminate carbide: $\mathrm{Ti}_{3} \mathrm{SnC}_{2} / /$ J. Am. Ceram. Soc. - 2007. - 90, N 8. - P. 2642-2644.

5. Lin Z. J., Zhuo M. J., Zhou Y. C. et al. Microstructures and theoretical bulk modulus of layered ternary tantalum aluminium carbides // Ibid. - 2006. - 89, N 12. - P. 3765-3769.

6. Pietzka M. A. Schuster J. C. Summary of constitutional data on the aluminium-carbontitanium system // J. Phase Equilib. - 1994. - 21, N 2. - P. 392-400.

7. Lane N. J., Vogel S. C., Caspi E. N., Barsoum M. W. $\mathrm{Ti}_{5} \mathrm{Al}_{2} \mathrm{C}_{3}$ : A new ternary carbide belonging to MAX phases in the Ti-Al-C system // J. Am. Ceram. Soc. - 2012. - 95, N 10. P. 3352-3354. 
8. Rao J. C., Pei Y. T., Yang H. J. et al. TEM study of the initial oxide scales of $\mathrm{Ti}_{2} \mathrm{AlC} / /$ Acta Mater. - 2011. - 59. - P. 5216-5223.

9. Wang H. C., Zhou Y. C. Oxidation behaviour of $\mathrm{Ti}_{3} \mathrm{AlC}_{2}$ at $1000-1400{ }^{\circ} \mathrm{C}$ in air // Corros. Sci. - 2003. - 45, N 5. - P. 891-907.

10. Lane N. J., Vogel S. C., Caspi E. N., Barsoum M. W. High-temperature neutron diffraction and First-principles study of temperature-dependent crystal structures and atomic vibrations in $\mathrm{Ti}_{3} \mathrm{AlC}_{2}, \mathrm{Ti}_{2} \mathrm{AlC}$, and $\mathrm{Ti}_{5} \mathrm{Al}_{2} \mathrm{C}_{3} / /$ J. Appl. Phys. - 2013. - 113. - P. 18-35.

11. Sundberg, M., et al. Alumina forming high-temperature silicides and carbides // Ceram. Int. 2004. - 30, N 7. - P. 1899-1904.

12. Gupta S., Filimonov D., Zaitsev V. et al. Ambient and $550{ }^{\circ} \mathrm{C}$ tribological behaviour of select MAX phases against Ni-based superalloys // Wear. - 2008. - 264, N 3-4. - P. 270-278.

13. Barnes L. A., Dietz Rago N. L., Leibowitz L. Corrosion of ternary carbides by molten lead // J. Nucl. Mater. - 2008. - 373. - P. 424-428.

14. Wang X. H., Zhou Y. C. Layered machinable and electrically conductive $\mathrm{Ti}_{2} \mathrm{AlC}$ and $\mathrm{Ti}_{3} \mathrm{AlC}_{2}$ ceramics // J. Mat. Sci. Technol. - 2010. - 26, N 5. - P. 385-416.

15. Gutzmann H., Gärtner F., Höche D. et al. Cold spraying of $\mathrm{Ti}_{2} \mathrm{AlC}$ MAX-Phase Coatings // J. Therm. Spray Technol. - 2013. - 22, N 2-3. - P. 406-412.

16. Eklund P., Beckers M., Jansson U. et al. The $\mathrm{M}_{n+1} \mathrm{AX}_{n}$ phases: Materials science and thinfilm processing // Thin Solid Films. - 2010. - 518, N 8. - P. 1851-1878.

17. Wilhelmsson O., Palmquist J.-P., Lewin E. et al. Deposition and characterization of ternary thin films within the Ti-Al-C system by DC magnetron sputtering // J. Cryst. Growth. 2006. - 291, N 1. - P. 290-300.

18. Frodelius J., Eklunda P., Beckersa M. et al. Sputter deposition from a $\mathrm{Ti}_{2} \mathrm{AlC}$ target: Process characterization and conditions for growth of $\mathrm{Ti}_{2} \mathrm{AlC} / /$ Thin Solid Films. - 2010. - 518. P. 1621-1626.

19. Rosen J., Ryves L., Persson P. O. A., M. Bilek M. M. Deposition of epitaxial $\mathrm{Ti}_{2} \mathrm{AlCTi}_{2} \mathrm{AlC}$ thin films by pulsed cathodic arc // J. Appl. Phys. - 2007. - 101, N 5. - P. 56101-56102.

20. Jiang J., Fasth A., Nylén P., Choi W. B. Microindentation and inverse analysis to characterize elastic-plastic properties for thermal sprayed $\mathrm{Ti}_{2} \mathrm{AlC}$ and NiCoCrAlY // J. Therm. Spray Technol. - 2009. - 18, N 2. - P. 194-200.

21. Frodelius J., Sonestedt M., Björklund S. et al. Ti ${ }_{2} \mathrm{AlC}$ coatings deposited by high velocity oxy-fuel spraying // Surf. Coat. Technol. - 2008. - 202, N 24. - P. 5976-5981.

22. Sonestedt M., Frodelius J., Sundberg M. et al. Oxidation of $\mathrm{Ti}_{2} \mathrm{AlC}$ bulk and spray deposited coatings // Corros. Sci. - 2010. - 52, N 12. - P. 3955-3961.

23. Papyrin A., Kosarev V., Klinkov S. et al. Cold spray technology. - NX Amsterdam: Elsevier Science, 2007.

24. Fung Y. C. Elasticity and thermodynamics. Foundations of solid mechanics / Ed. Englewood Cliffs. - NJ: Prentice Hall International, 1965.

25. Trentin A. et al. Microstructure and mechanical properties of cold spray titanium coatings // Proc. Int. Thermal Spray Conf. and Exposition "Thermal Spray: Global Solutions for Future Application”, Singapore, 3-5 May, 2010, Dusseldorf: DVS-Berichte. - 264. - P. 654-656.

26. Dykhuizen R. C., Smith M. F., Gilmore D. L. et al. Impact of high velocity cold spray particles // J. Therm. Spray Technol. - 1999. - 8, N 4. - P. 559-564.

27. Gutzmann H., Gärtner F., Höche D. et al. Cold Spraying of Ti ${ }_{2} \mathrm{AlC}$ MAX-Phase Coatings // Ibid. - 2013. - 22, N 2. - P. 406-412.

28. Schmidt T., Assadi H., Gärtner F. et al. From particle acceleration to impact and bonding in cold spraying // Ibid. - 2009. - 18, N 5-6. - P. 794-808.

29. Verstak A., Baranovski V. Deposition of carbides by activated combustion of HVAF Spraying // Proc. Int. Thermal Spray Conf. and Exposition "Thermal Spray Solutions: Advances in Technology and Application”, Osaka, Japan, 10-14 May, 2004, Dusseldorf: DVS-German Welding Society. - P. 551-556.

30. Jacobs L., Hyland M. M., De Bonte M. Comparative study of WC-cermet coatings sprayed via the HVOF and the HVAF Process // J. Therm. Spray Technol. - 1998. - 7, N 2. - P. 213218.

31. Jacobs L., Hyland M. M., De Bonte M. Study of the influence of microstructural properties on the sliding-wear behavior of HVOF and HVAF sprayed WC-cermet coatings // Ibid. 1999. - 8, N 1. - P. 125-132.

32. Guo R. Q., Zhang C., Chen Qi, Liu Liangwei. Study of structure and corrosion resistance of Fe-based amorphous coatings prepared by HVAF and HVOF // Corros. Sci. - 2011. - 53, N 7. - P. 2351-2356. 
33. Hess J. B., Barrett C. S. Structure and nature of kink-bands in zinc // Trans. AIME. - 1949. 185. - P. 599-605.

34. Barsoum M. W., El-Raghy T. The MAX phases: unique new carbide and nitride materials // American Scientist. - 2001. - 89, N 4. - P. 334-343.

35. Bei, G-P. Guitton A., Joulain A. et al. Pressure-enforced plasticity in MAX phases: from single grain to polycrystal investigation // Philos. Mag. - 2013. - 93, N 15. - P. 1784-1801.

36. Kawakita, J. Katanoda H., Watanabe M., Kuroda S. Warm spraying: An improved spray process to deposit novel coatings // Surf. Coat. Technol. - 2008. - 202. - P. 4369-4373.

37. Guo J. M., Chen K. X., Liu Guanghua, Ning Xiao-Shan. Effects of TiC and $\mathrm{Ti}_{3} \mathrm{AlC}_{2}$ addition on combustion synthesis of $\mathrm{Ti}_{3} \mathrm{AlC}_{2}$ powders // Rare Metal Mater. Eng. - 2003. - 32, N 3. P. 20-23.

38. Ma X. L., Zhu Y. L., Wang X. H., Zhou Y. C. Microstructural characterization of bulk $\mathrm{Ti}_{3} \mathrm{AlC}_{2}$ ceramics // Philos. Mag. A. - 2004. - 84, N 28. - P. 2969-2977.

39. Hong X. L., Mei B., Zhu J., Zhou W. Fabrication of $\mathrm{Ti}_{2} \mathrm{AlC}$ by hot pressing of Ti, TiC, Al, and active carbon powder mixtures // J. Mat. Sci. - 2004. - 39, N 5. - P. 1589-1592.

40. Sonestedt M., Frodelius J., Palmquist J. P. et al. Microstructure of high velocity oxy-fuel sprayed $\mathrm{Ti}_{2} \mathrm{AlC}$ coatings // Ibid. - 2010. - 45, N 10. - P. 2760-2769.

41. Zhang J., et al. Structure stability of $\mathrm{Ti}_{3} \mathrm{AlC}_{2}$ in $\mathrm{Cu}$ and microstructure evolution of $\mathrm{Cu}-\mathrm{Ti}_{3} \mathrm{AlC}_{2}$ composites // Acta Mater. - 2007. - 55. - P. 4381-4390.

Received 06.03.17 